\title{
Investigation into the Customer Loyalty and Corporate Image Relationship
}

\author{
Rashmi Jain \\ N L Dalmia Institute of Management Studies and Research, India
}

\begin{abstract}
While extant of academic literature shows that service quality and customer satisfaction are key to building customer loyalty, given these equitable, "Does corporate image create loyalty" is the question this research probes. A primary research was conducted among the mobile communication subscribers. A total of 550 subscribers of mobile communication services in Mumbai, India were approached. Of this, 400 complete and valid responses were collected. Findings suggest that corporate image and the service quality perceived by the customers have a strong relationship with customer loyalty. This implies that both external marketing and interactive marketing dimensions have a direct impact on building customer loyalty. Customer satisfaction was seen to be completely mediating the relationship between service quality and customer loyalty. This research provides a model that can help the managers of service organizations to enhance customer loyalty. Since corporate image positively impacts the customer loyalty along with service quality, it is important for the industry managers to devote equal attention and resources in delivering the promise as well building a good image of the company. Since the service quality impacts the corporate image, an important takeaway for the managers is to ensure that the actual offer matches promises made externally. Most of the previous studies investigating the antecedents of customer loyalty have either focused on the interactive marketing dimension or the external marketing dimension. This study examines the interplay of both the dimension and its impact on customer loyalty.
\end{abstract}

Keywords: corporate image, customer loyalty, customer satisfaction, service quality

\section{Introduction}

Customer loyalty is the extent to which a customer shows repeat purchasing behavior from a provider, possesses a positive attitudinal disposition toward the provider, and considers using only this provider when a need arises.

Since Reichheld (1996) highlighted the impregnable advantage of customer loyalty, by stating that that profitability can be increased as much as $125 \%$ by retaining the old customers and acquiring their loyalty; practitioners and academics alike have realized that a focus on long-term relational bonds with customers which positively impacts the profitability is paramount. Many studies have investigated need and importance of customer loyalty. Some of the arguments supporting customer loyalty's contribution to the organizational success are that it costs less to keep existing customers than to attract new ones and that loyal customers may advocate organization's products and services by spreading positive word of mouth, as well as the idea that long-term customers can be more easily up- and cross-sold (Heskett, Jones, Loveman, Sasser, \& Schlesinger, 
1994; Reichheld \& Sasser, 1990). Importance of customer loyalty sparked lot of interest and intrigue among researchers of both service and manufacturing sectors.

A review of extant of service marketing literature advocates that in order to attain long-term success service organizations do not only have to consider external marketing, i.e., how to interact with customers through communication messages, but also on interactive marketing, i.e., how the promises made in the external communication messages are actually delivered to the customer. Service Triangle (Zeithaml, Bitner, Gremler, \& Pandit, 2013) proposes, both, the external, as well as the interactive marketing dimension, are critical in creating customers' attitudes during service delivery. The customers' expectations towards the service are largely based on the image of the service provider which has been shaped by the external communication messages. Consumption of the service impacts the customers' perception of the service delivered. Parasuraman, Zeithmal, and Berry (1985) suggested that customer's perception of service quality is the gap or difference between the expected level of service provider's performance and the performance experienced by the customer.

Due to three unique features of services - intangibility, heterogeneity, and inseparability (Parasuraman, Zeithmal, \& Berry, 1988), it is challenging for organizations in service industry to effectively and realistically communicate the true nature and deliverables of the service intended (Singh \& Sirdeshmukh, 2000). Hence it is critical to understand how the interactive marketing dimension along with the external marketing dimension influences customer satisfaction and customer loyalty. Hence the objective of the study is to investigate how corporate image (primarily created through external marketing activities) and service quality perceptions impact customer satisfaction and customer loyalty.

\section{Literature Review, Hypotheses, and Research Model}

\section{Customer Loyalty}

Customer loyalty is the degree to which a customer exhibits repeat purchasing behavior from a provider, possesses a positive attitudinal disposition toward the provider, and considers using only this provider when a need arises. According to Reichheld (1996), customers may become loyal to business that can deliver superior value relative to the offerings of competitors. Studies have shown that customer loyalty is a multidimensional concept (Oliver, 1997; Zeithaml, Bitner, Gremler, \& Pandit, 2013).

Customer loyalty is a matter of degree, ranging from the completely loyal customer to one who will never consider using another provider in the future. Hence, an extremely loyal customer is one who (a) regularly uses a service provider, (b) really likes the organization and thinks very highly of it, and (c) does not ever consider using another service provider for this service. Conversely, an extremely "non-loyal" person (a) will never use the provider again, (b) has negative feelings toward the organization, and (c) welcomes suggestions about other providers and is willing to try any other provider (Zeithaml, Bitner, Gremler, \& Pandit, 2013).

\section{Customer Satisfaction \& Loyalty}

Satisfaction plays a central role in marketing because it is a good predictor of purchase behavior (Oliver, 1997). Customer satisfaction is the feeling of pleasure or disappointment that comes from judging a product's perceived performance to their expectations (Kotler, Keller, Koshy, \& Jha, n.d.). Thus, a customer is dissatisfied if the result of the interaction falls short of expectations, satisfied if it matches expectations, and delighted if it exceeds expectations. Customer satisfaction is, therefore, an overall evaluation based on the 
purchase and consumption experience with a product or service over time (Oliver, 1997; Anderson, Fornell, \& Lehmann, 1994).

Various studies have investigated the construct of customer satisfaction and have provided evidence of customer satisfaction being an important determinant of customer loyalty (Mittal, Ross, \& Baldasare, 1998; Caruana, 2002; Shah \& Schaefer, 2005). Wang and Shieh (2006) and Sweeney and Swait (2008) have shown that a satisfied customers' attitude toward a service provider could motivate the customer to make repeat purchases and even endorse the service provider to others thereby improving the organization's profitability. Research in the banking industry by Kandampully (1998) and Siddiqi (2011) has demonstrated the significant positive impact of customer satisfaction on customer loyalty. Sivadas and Baker-Prewitt (2000) and Liu, Guo, and Lee (2011) deduced customer satisfaction to be a strong predictor of customer loyalty in the retail industry.

Although there is widespread agreement on the important role of customer satisfaction in establishing customer loyalty, some researchers argue that it is not natural that customer satisfaction will lead to customer loyalty (Mittal, Ross, \& Baldasare, 1998; Gustafsson, Johnson, \& Roos, 2005) because it is possible to find situations where customers change their patronage despite high level of satisfaction. This study argues that customer satisfaction is an important determinant of customer loyalty because satisfied customers have a propensity to make repeat purchases and repeat purchases may result in the development of relationship which enhances customer loyalty. Hence, the following hypothesis is:

H1: Customer satisfaction has a positive impact on customer loyalty.

\section{Service Quality}

Service quality is more difficult to measure as compared to the measurement of quality of goods (Parasuraman, Zeithmal, \& Berry, 1985). At the time of purchase in the case of goods, various tangible attributes like shape, size, color, package, etc., can be checked properly and quality can be assessed. But in the case of services, because of intangible nature, it is difficult to make an assessment of their quality before their purchase. Therefore in the case of services purchasing procedure various other tangible attributes like personnel of service providers, their equipments, and physical facilities, etc., can be taken as measures of quality assessment.

Parasuraman, Zeithmal, and Berry (1988) defined service quality as difference between the expected level of service provider's performance and the performance experienced by the customer across five key dimensions - tangibles, reliability, responsiveness, assurance, empathy. Many researchers (Teas, 1993; Boulding, Kalra, Staelin, \& Zeithaml, 1993; Dabholkar, 1996) have investigated service quality using this concept across various industries.

Many Researchers have demonstrated the positive relationship between perceived quality and loyalty (Bitner, Booms, \& Tetreault, 1990; Fornell, Johnson, Anderson, Cha, \& Bryant, 1996; Zeithaml, Berry, \& Parasuraman, 1996). The study conducted by Zeithaml et al. (1996) found a positive and significant relationship between customer's perceptions of service quality and their desire to recommend the company. Fornell et al. (1996) highlighted that service quality has a positive impact on customer retention, which was strongly related to profitability. Similarly, Boulding et al. (1993) found positive relationships between service quality, repurchase intentions, and positive word of mouth. However, there are also some studies that could not find a positive relationship between service quality and behavioral intentions (Hu, Kandampully, \& Juwaheer, 2009). Hence, the study proposes the following hypotheses: 
H2: Service quality has a positive impact on customer satisfaction.

H3: Service quality has a positive impact on customer loyalty.

H4: Service quality has a positive impact on corporate image.

\section{Corporate Image}

Corporate image is referred to as the overall impressions made on the minds of the public about a firm. Gronroos (1988) describes the corporate image is a perception of the organization held in consumer memory and worked as a filter that influences the perception of the operation of the company and the customers' behavioral intentions. Nguyen and Leblanc (July 2001) stated that the corporate image impacted by behavioral and physical attributes of the company like interacton with the firm, variety of products offered, business architecture and name etc. Marketing communications can strongly shape corporate image among potential customers and can initiate first purchase intentions. Yavas, Bilgin, and Shemwell (1997) suggested that corporate image is a very strong differentiating factor for an organization and reduce customer's perceived risk. Thus a strong corporate image can lead to first time purchase among new customers and loyalty in the existing customers (Andreassen \& Lindestad, 1998).

Various researches have shown that corporate image can have a direct impact on loyalty (Andreassen \& Lindestad, 1998; Dick \& Basu, 1994; Nguyen \& Leblanc, 2001). Studies have also shown that there is a relationship between image and satisfaction (Bloemer \& Ruyter, 1998). Therefore, our study proposes the following hypotheses:

H5: Corporate image has positive impact on customer satisfaction.

H6: Corporate image has positive impact on customer loyalty.

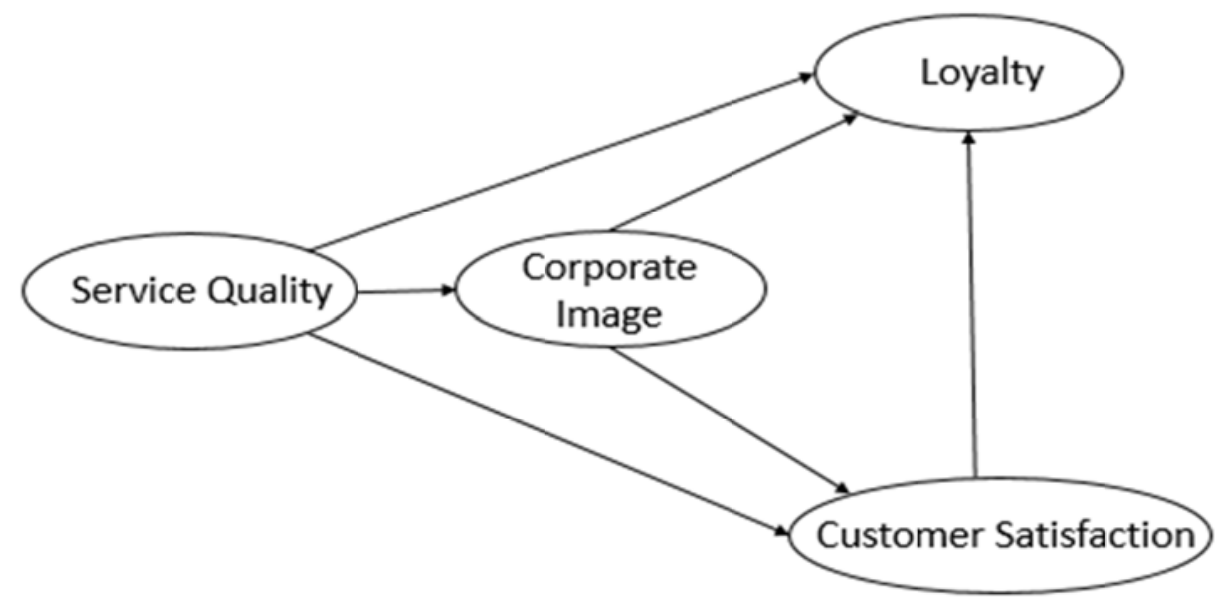

Figure 1. Research model.

\section{Research Methodology}

The survey instrument for this research was developed based on previous studies. It consists of close-ended questions which recorded the responses on a 7-point where 1 indicated strongly disagree and 7 indicated strongly agree.

Service quality was measured using the most popular SERVQUAL developed by Zeithmal et al. (1996) and the extended SERVQUAL (Seth, Momaya, \& Gupta, 2008) instrument which determines service quality structure along with technical quality (network clartity, coverage etc.). Customer satisfaction has been 
measured using the instruments developed by Turel and Serenko (2006) and Van and Verhoef (2008). Instruments developed by Ganesh, Arnold, and Reynolds (2000), Gustafsson, Johnson, and Roos (2005), and Denga, Lu, Wei, and Zhang (2009), which were used to measure the customer loyalty. Items in the questionnaire pertaining to corporate image were adapted from instruments developed by Selnes (1993) and Gi-Du and Jeffrey (2004).

A total of 550 subscribers of mobile communication services in Mumbai, India were approached. Of this, 400 complete and valid responses were collected.

\section{Analysis and Results}

The research model proposed by the study was tested using structural equation modeling using AMOS 25 . After establishing the reliability and validity of the constructs, the data were analyzed in two stages - first, the measurement model was tested goodness-of-fit then path coefficients of the structural model were analyzed to assess the relationship between various constructs.

\section{Reliability and Validity}

Cronbach's alpha is used to test the reliability of the interval scaled variables. Cronbach's alpha coefficient value greater than 0.75 indicates good reliability or a strong internal consistency (Malhotra \& Dash, 2016).

Convergent validity was evaluated using criteria recommended by Fornell and Larcker (1981) — construct reliabilities must exceed 0.70, and Average Variance Extracted (AVE) by each construct must exceed the variance due to measurement error for that construct (that is, AVE should exceed 0.50).

Table 1

Reliability and Convergent Validity

\begin{tabular}{lll}
\hline Construct & Cronbach's alpha & AVE \\
\hline Service quality & 0.852 & 0.619 \\
Customer satisfaction & 0.903 & 0.822 \\
Corporate image & 0.860 & 0.650 \\
Customer loyalty & 0.800 & 0.659 \\
\hline
\end{tabular}

Discriminant validity is assessed from the latent variable correlation matrix. The following table presents the correlations between the latent variables in the lower left, off-diagonal elements of the matrix, and the square root of the AVE. Discriminant validity is satisfactory if the diagonal values are larger than the off-diagonal values (Fornell \& Larker, 1981). Table 2 shows that these conditions are satisfied.

Table 2

Discriminant Validity

\begin{tabular}{lllll}
\hline Construct & Service quality & Customer satisfaction & Corporate image & Customer loyalty \\
\hline Service quality & 0.785 & 0.777 & 0.752 & 0.660 \\
Customer satisfaction & & 0.908 & 0.772 & 0.756 \\
Corporate image & & 0.805 & 0.677 \\
Customer loyalty & & & 0.812 \\
\hline
\end{tabular}

Thus, from Tables 1 and 2, it is deduced that each construct exhibited high level of reliability and validity.

\section{Structural Equation Model Testing \& Path Analysis}

The fitness of a model could be tested using a various goodness-of-fit as detailed in Table 3. Hair, Black, 
Babin, and Anderson (2016) recommend that for a more robust analysis more than one fit index is required, representing Absolute Fit Indices (GFI, RMSEA, RMR, Normed Chi-Square, AGFI), Incremental Fit Indices (NFI, TLI, CFI), and Parsimony Fit Indices (PGFI, PNFI).

Table 3

Goodness of Fit Indices

\begin{tabular}{lll}
\hline Goodness-of-fit measure & Recommended cut-off value (Source: Chau, 1997) & Observed values \\
\hline Normed Chi-Square $\left(\chi^{2} / \mathrm{df}\right)$ & $2 \leq\left(\chi^{2} / \mathrm{df}\right) \leq 5$ & 3.704 \\
GFI & $\geq 0.9$ & 0.947 \\
AGFI & $\geq 0.8$ & 0.938 \\
RMSEA & $\leq 0.1$ & 0.082 \\
CFI & $\geq 0.9$ & 0.925 \\
NFI & $\geq 0.9$ & 0.901 \\
TLI & $\geq 0.9$ & 0.919 \\
\hline
\end{tabular}

From the Table 3, it is seen that the goodness-of-fit indices' observed values meet the criteria for an acceptable model. Hence it can be inferred that the model under study consisting of service quality, customer satisfaction, corporate image, and loyalty is a well fit and acceptable model.

Table 4

Path Analysis

\begin{tabular}{llll}
\hline Hypotheses & Path & Standardized estimate & Remark \\
\hline H1 & Cust. Sat $\rightarrow$ Loyalty & $0.861^{* * *}$ & Supported \\
H2 & Quality $\rightarrow$ Cust. Sat & $0.891^{* * *}$ & Supported \\
H3 & Quality $\rightarrow$ Loyalty & 0.059 & Not supported \\
H4 & Quality $\rightarrow$ Corp. Image & $0.827^{* * *}$ & Supported \\
H5 & Corp. Image $\rightarrow$ Cust. Sat & $0.638^{* * *}$ & Supported \\
H6 & Corp. Image $\rightarrow$ Loyalty & $0.742^{* * *}$ & Supported \\
\hline
\end{tabular}

Note. ***Significant at $\mathrm{p}<0.001$.

The path coefficients are also known as regression weights which indicate the magnitude of change in the dependent variable for each unit change in the independent variable. For the path coefficient to be statistically significant the p-value should be less than 0.05 . The path coefficients given in the table above are used to analyze the relationships among the various constructs.

Based on the Table 4 it is can be deduced that:

(1) Service quality has a direct impact on customer satisfaction (std. estimate $=0.891$; p-value $<0.001$ ) and corporate image (std. estimate $=0.827 ; \mathrm{p}$-value $<0.001$ )

(2) Corporate image has a direct impact on customer satisfaction (std. estimate $=0.638 ; \mathrm{p}$-value $<0.001$ ) and customer loyalty (std. estimate $=0.742 ; \mathrm{p}$-value $<0.001$ ).

(3) Customer satisfaction has a direct impact on customer loyalty (std. estimate $=0.861$; $p$-value $<0.001$ ).

(4) The relationship between service quality and customer loyalty is not established (std. estimate $=0.059$; $\mathrm{p}$-value $=0.596$ ). Hence the mediating role of customer satisfaction in the relationship of service quality and customer loyalty was checked.

Baron and Kenny (1986) state that the mediator variable describes relationship between dependent variable and predictor variable. The process of complete mediation is defined as the complete intervention 
caused by the mediator variable. This results in the initial predictor variable no longer affecting the dependent variable. The steps suggested by Baron and Kenny were implemented in this study, where the predictor variable is service quality, the outcome variable is loyalty, and the mediating variable is customer satisfaction. In the absence of mediation variable, the path coefficient for service quality to loyalty is 0.808 (p-value $<0.05$ ) indicating a statistically siginificant direct and positive relationship. However, when the mediating variable customer satisfaction is introduced, the standardized estimate for path from customer satisfaction to loyalty is 0.861 at $p$-value $<0.05$ indicating a strong statistically significant relationship between customer satisfaction and loyalty. But in the presence of customer satisfaction, the standardized estimate between service quality and loyalty is 0.059 at $\mathrm{p}$-value $>0.05$, indicating a statistically insignificant relationship. Thus in presence of the mediating variable customer satisfaction, the relationship between service quality and loyalty has become insignificant. Hence it is concluded that customer satisfaction completely mediates the relationship between service quality and loyalty.

\section{Discussions and Implications}

Loyalty which leads to long term profitability of an organization has intrigued many researchers. This had triggered various studies investigating the antecedants of customer loyalty. Through the literature review, it was found that most of the studies either focused on practices on the interactive marketing dimension, or on external marketing dimension that impacted customer loyalty. Based on the Service Triangle concept (Zeithaml, Bitner, Gremler, \& Pandit, 2013), researcher argued that both these dimensions may play a role in forming customers' satisfaction and customer loyalty and hence should be evaluated together. This study has attempted to fill this gap by determining the interrelationship of service quality, corporate image, customer satisfaction, and customer loyalty.

Findings suggest that the coporate image of the service provider and the service quality perceived by the customers have a strong relationship with customer loyalty. This implies that both external marketing and interactive marketing dimensions have a direct imapct on building customer loyalty. Further, corporate image and service quality significantly and positively imapct customer satisfaction. Customer satisfaction was seen to be completely mediating the relationship between service quality and customer loyalty. The study also showed a strong and positive relation between corporate image and service quality. This implies that the corporate image is created not just by the external marketing (Yavas, Bilgin, \& Shemwell, 1997), but also interactive marketing, thus highlighting that both marketing dimensions are intertwined.

\section{Managerial Implications}

Customer loyalty is the key to retaining existing customers and acquiring new customers at lower cost. It also enhances the long term profitability of an organization. This study has shown that the customer loyalty is affected by both corporate image and service quality, i.e., both external marketing and internal marketing. Hence the managers need to strike a balance in allocating funds for both the kind of marketing activities.

Since the service quality impacts the corporate image, an important takeaway for the managers is to ensure that the actual offer matches promises made externally, as perceptions of the performed service will be compared with the organizational image held before the service encounter, both of which will affect the customer satisfaction and loyalty. 


\section{Future Research Implications}

The present study has measured the relationship between service quality, customer satisfaction, corporate image, and customer loyalty in a single service sector in India. Researcher suggests the replication of this study in other sectors in order to test the generalizability of the study.

\section{Statement of Conflict of Interest}

On behalf of all authors, the corresponding author states that there is no conflict of interest.

\section{References}

Anderson, E., \& Mittal, V. (2000). Strengthening the satisfaction-profit chain. Journal of Service Research, 3(2), 107-120.

Anderson, E., Fornell, C., \& Lehmann, D. (1994). Customer satisfaction, market share, and profitability: Findings from Sweden. Journal of Marketing, 58(3), 53-66.

Andreassen, T. W., \& Lindestad, B. (1998). Customer loyalty and complex services: The impact of corporate image on quality, customer satisfaction and loyalty for customers with varying degrees of service expertise. International Journal of Service Industry Management, 9(1), 7-23.

Baron, R. M., \& Kenny, D. A. (1986). The moderator-mediator variable distinction in social psychological research: Conceptual, strategic, and statistical considerations. Journal of Pernality and Social Psychology, 51(6), 1173-1182.

Bitner, M. J., Booms, B. H., \& Tetreault, M. S. (Jan. 1990). The service encounter: Diagnosing favorable and unfavorable incidents. Journal of Marketing, 54(1), 71-84.

Bloemer, J., \& Ruyter, K. (1998). On the relationship between store image, store satisfaction and store loyalty. European Journal of Marketing, 32(5-6), 499-513.

Boulding, W., Kalra, A., Staelin, R., \& Zeithaml, V. A. (1993). A dynamic process model of service quality: From expectations to behavioural intentions. Journal of Marketing Research, 30(1), 7-27.

Caruana, A. (2002). Service loyalty: The effects of service quality and the mediating role of customer satisfaction. European Journal of Marketing, 36(7/8), 811-828.

Chau, P. Y. (1997). Reexamining a model for evaluating information center success using a structural equation modeling approach. Decision Sciences, 28(2), 309-334.

Dabholkar, P. (1995). A contingency framework for predicting causality between customer satisfaction and service quality. Advances in Consumer Research, 22, 101-108.

Dabholkar, P. A. (1996). Consumer evaluations of new technology-based self-service options: An investigation of alternative models of service quality. International Journal of Research in Marketing, 13(1), 29-51.

Denga, Z., Lu, Y., Wei, K. K., \& Zhang, J. (2009). Understanding customer satisfaction and loyalty: An empirical study of mobile instant messages in China. International Journal of Information Management, 30(4), 289-300.

Dick, A., \& Basu, K. (1994). Customer loyalty: Toward an integrated conceptual framework. Journal of the Academy of Marketing Science, 22(2), 99-113.

Fornell, C., \& Larcker, D. (1981). Evaluating structural equation models with unobservable variables and measurement error. Journal of Marketing Research, 18(1), 39-50.

Fornell, C., Johnson, M., Anderson, E., Cha, J., \& Bryant, B. (1996). The American customer satisfaction index: Nature, purpose, and findings. Journal of Marketing, 60(4), 7-18.

Ganesh, J., Arnold, M., \& Reynolds, K. (2000). Understanding the customer base of service providers: An examination of the differences between switchers and stayers. Journal of Marketing, 64(3), 65-87.

Gi-Du, K., \& Jeffrey, J. (2004). Service quality dimensions: An examination of Gronroos's service quality model. Managing Service Quality, 14(4), 266-277.

Gronroos, C. (1984). A service quality model and its marketing implications. European Journal of Marketing, 18(4), 36-44.

Gronroos, C. (1988). Service quality: The six criteria of good perceived service. Review of Business, 9(3), 10-19.

Gustafsson, A., Johnson, M., \& Roos, I. (2005). The effects of customer satisfaction, relationship commitment dimensions, and triggers on customer retention. Journal of Marketing, 69(4), 210-218.

Hair, J. F., Black, W. C., Babin, B. J., \& Anderson, R. E. (2016). Multivariate data analysis. Noida: Pearson India Education Services Pvt. Ltd. 
Heskett, J., Jones, T., Loveman, G., Sasser, E., \& Schlesinger, L. (1994). Putting the service-profit chain to work. Harvard Business Review, 72(2), 164-174.

Hu, H. H., Kandampully, J., \& Juwaheer, T. D. (2009). Relationships and impacts of service quality, perceived value, customer satisfaction, and image: An empirical study. Service Industries Journal, 29(2), 111-125.

Kandampully, J. (1998). Service quality to service loyalty; a relationship which goes beyond customer services. Total Quality Management Journal, 9(6), 431-443.

Kotler, P., Keller, K., Koshy, A., \& Jha, M. (n.d.). Marketing management-a South Asian perspective (14th ed.). London: Pearson.

Liu, C.-T., Guo, Y. M., \& Lee, C.-H. (2011). The effects of relationship quality and switching barriers on customer loyalty. International Journal of Information Management, 31(1), 71-79.

Malhotra, N. L., \& Dash, S. (2016). Marketing research—an applied orientation. Noida: Pearson India Education Services Pvt. Ltd.

Mittal, V., Ross, W., \& Baldasare, P. M. (1998). The asymmetric impact of negative and positive attribute-level performance on overall satisfaction and repurchase intentions. Journal of Marketing, 62, 33-47.

Nguyen, N., \& Leblanc, G. (July 2001). Corporate image and corporate reputation in customers' retention decisions in services. Journal of Retailing and Consumer Services, 8(4), 227-236.

Oliver, R. (1980). A cognitive model of the Antecedents and consequences of satisfaction decisions. Journal of Marketing Research, 17(4), 460-469.

Oliver, R. L. (1997). Satisfaction: A behavioral perspective on the consumers. NY: Routledge.

Olsen, L. L., \& Johnson, M. D. (2003). Service equity, satisfaction, and loyalty: From transaction-specific to cumulative evaluations. Journal of Service Research, 5, 184-197.

Parasuraman, A., Zeithmal, V., \& Berry, L. (1985). A conceptual model of service model and its implications for future research. Journal of Marketing. pp. 41-50.

Parasuraman, A., Zeithmal, V., \& Berry, L. (1988). SERVQUAL: A multiple item scale for measuring consumer perception of service quality. Journal of Retailing, 64(1), 12-37.

Reichheld, F. (1996). Learning from customer defections. Harvard Business Review, 72(2), 56-69.

Reichheld, F., \& Sasser, E. (1990). Zero defections: Quality comes to services. Harvard Business Review, 68(5), 105-113.

Rust, R. T., \& Oliver, R. L. (1994). Service quality: Insights and managerial implications from the frontier. In R. T. Rust and R. L. Oliver, Service quality: New directions in theory and practice (pp. 1-19). Thousand Oaks, California: Sage Publications.

Selnes, F. (1993). An examination of the effect of product performance on brand reputation, satisfaction and loyalty. European Journal of Marketing, 27(9), 19-35.

Seth, A., Momaya, K., \& Gupta, H. M. (January-March 2008). Managing the customer perceived service quality for cellular mobile telephony: An empirical investigation. Vikalpa-The Journal for Decision Makers, 33, 19-34.

Shah, A., \& Schaefer, A. D. (2005). Switching service providers: Who will the consumer switch to? Services Marketing Quarterly, 27(1), 73-91.

Siddiqi, K. O. (2011). Interrelations between service quality attributes, customer satisfaction and customer loyalty in the retail banking sector in Bangladesh. International Journal of Business and Management, 6(3), 12-36.

Singh, J., \& Sirdeshmukh, D. (2000). Agency and trust mechanisms in consumer satisfaction and loyalty judgements. Journal of the Academy of Marketing Science, 28(1), 150-167.

Sivadas, E., \& Baker-Prewitt, J. (2000). An examination of the relationship between service quality, customer satisfaction, and store loyalty. International Journal of Retail \& Distribution Management, 28(2), 73-82.

Sweeney, J., \& Swait, J. (2008). The effects of brand credibility on customer loyalty. Journal of Retailing \& Consumer Services, 15(3), 179-193.

Teas, K. (1993). Expectations, performance evaluation, and consumers' perceptions of quaiity. Journal of Marketing, 57, 18-34.

Turel, O., \& Serenko, A. (2006). Satisfaction with mobile services in Canada: An empirical investigation. Telecommunication Policy, 30, 14-331. Retrieved from http://www.sciencedirect.com/science/article/pii/S0308596106000267

Van, D., \& Verhoef, P. (2008). Critical incidents and the impact of satisfaction on customer share. Journal of Marketing, 72(4), 123-142.

Wang, M., \& Shieh, C.-J. (2006). The relationship between service quality and customer satisfaction: The example of CJCU library. Journal of Information and Optimization Sciences, 27(1), 193-209. 


\section{INVESTIGATION INTO THE CUSTOMER LOYALTY AND CORPORATE IMAGE RELATIONSHIP405}

Yavas, U., Bilgin, Z., \& Shemwell, D. J. (1997). Service quality in the banking sector in an emerging economy: A consumer survey. International Journal of Bank Marketing, 15(6/7), 116-123.

Zeithaml, V. A., Berry, L. L., \& Parasuraman, A. (1996). The behavioral consequences of service quality. Journal of Marketing, 60(4), 31-46.

Zeithaml, V. A., Bitner, M., Gremler, D., \& Pandit, A. (2013). Services marketing-integrating customer focus across the firm. New Delhi: McGraw Hill Education. 